\title{
Western Sahara
}

National Cancer Institute

\section{Source}

National Cancer Institute. Western Sahara. NCI Thesaurus. Code C20113.

A country in northern Africa, bordering the North Atlantic Ocean, between Mauritania and Morocco. 